\title{
A SZCENÁRIÓELEMZÉSEN ALAPULÓ HADERŐFEJLESZTÉS LEHETSÉGES MÓDSZERE AZ MH KÉPESSÉGFEJLESZTÉSE ÉRDEKÉBEN
}

\author{
DOI: $10.35926 / \mathrm{HSZ} .2020 .4 .6$
}

\begin{abstract}
ÖSSZEFOGLALÓ: A szerző írásában az általános morfológiai elemzést és a NATO alternatív elemzést felhasználva mutatja be a lehetséges jövőbeni szcenáriók alapvető tényezőinek meghatározását. E tényezők meghatározásával felállithatók a katonai képességekre vonatkozó megállapítások, melyek lehetővé teszik a jövő kihívásaira minden szinten megfelelni tudó haderő kialakítását.
\end{abstract}

KULCSSZAVAK: általános morfológiai elemzés, GMA, Fritz Zwicky, NATO alternatív elemzés, kvalitativ elemzés, kvantitatív elemzés, biztonsági környezet elemzése, képességfejlesztés, haderő, védelmi tervezés, haderőtervezés, Magyar Honvédség

\section{BEVEZETÉS}

Jövőkutatás. Sokak által támogatott, de még többek által megkérdőjelezett tudomány. Alkalmazások, elgondolások, technikák összessége, mely arra hivatott, hogy a jelen történései alapján a lehető legnagyobb pontossággal készítsen előrejelzéseket a jövőre vonatkozóan. A,jövőkutatás" folyamatosan jelen volt az emberiség történetében, mondáiban és történeteiben. Modern formában azonban csak az ötvenes évek elejétől beszélhetünk jövőkutatásokról, amikor a kutatók tudományos módszerek alkalmazásával próbáltak meg előrejelzéseket adni, stratégiai irányokat meghatározni. Ahogy dr. Nováky Erzsébet a Budapesti Corvinus Egyetem Jövőkutatás Tanszékének programvezetője írja tanulmányában: „A jövőkutatók tudományos eszközökkel vizsgálták, miként ismerhetö meg a jövö, hogyan állíthatók elö ismeretek a még nem létező folyamatokról, eseményekröl, kapcsolatokról és állapotokról. Vizsgálták a jövövel való foglalkozás tudományelméleti kérdésköreit (mint például a jövö megismerhetöségének és meghatározottságának, valamint az alternativákban való gondolkodásnak a lehetöségeit), kidolgozták és szélesedö körben alkalmazták azokat a módszereket, amelyeket a jövö megismerése eszközeként eredményesnek itéltek. Feltárták a fejlödés nagy tendenciáit és a társadalmi-gazdasági jövö lehetséges változatait."

Ennek ellenére manapság is úgy tűnik, hogy a döntéshozók, vezetők nem nagyon fogadták meg a kutatók által leírt gondolatokat. Meglátásom szerint - egy-két kivételtől eltekintve - a haderők fejlesztésekor nem alkalmazzák a jövő kutatásának tudományos módszereit, a döntések rövid távú elörejelzéseken alapulnak, melyek szorosan kapcsolódnak a

Dr. Nováky Erzsébet: Jövőkutatási tanulmányok 1998-2005. Oktatási-szakképzési jövőalternatívák új szemléletben. A Budapesti Corvinus Egyetem Jövőkutatás Tanszéke és a Magyar Szakképzési Társaság Kutatói Tagozata 2004. június 28-i ülésén tartott előadás írásos változata. Megjelent: Szakképzési Szemle, 2005/3., 290 -316. https://mek.oszk.hu/04100/04129/04129.pdf (Letöltés időpontja: 2020. 04. 15.) 
rendelkezésre álló forráskeretekhez. A döntéshozás szintjén megjelenő dokumentumok nem tartalmazzák azokat a stratégiai irányokat és az elérendő célokat 30-35 éves időtávlatokban, melyek elengedhetetlenek egy haderő fejlesztésének megkezdése előtt.

Ilyenkor fel kell tenni a kérdést, hogy miért olyan nehéz ezeket a stratégiai célokat kitűzni. Nem lehetséges, vagy csak nem rendelkezünk azokkal a tudományos alapokkal, melyek lehetővé teszik e célok megbízható megfogalmazását?

George Friedman a The Next 100 Years: A Forecast for the $21^{\text {st }}$ Century címü könyvében a következőket írja: „,Lehetetlen a következö évszázad pontos részleteit elöre jelezni - attól eltekintve, hogy addigra már rég halott leszek, és nem fogom tudni, milyen hibákat vétettem. De állitom, hogy valóban láthatók az általános körvonalai annak, hogy mi fog történni, és hogy megpróbáljunk annak néhány definíciót adni, bármilyen definíciót is jelent ez.”2

Természetesen nincs kristálygömb a kezünkben, mely azonnal megmondja nekünk a jövőt, és nem használhatunk minden tudományt nélkülöző jóslásokat sem, de ahogy azt Bethlen Gábor is kimondta, mindent, amit lehet, meg kell tenni annak érdekében, hogy legalább a lehetséges jövő irányait tudományos alapokon definiáljuk, jellemezzük és a jelenben meghozandó fontos döntések alapjait lefektessük.

A jövőt leírni nem egyszerü feladat, így annak meghatározására is több nézet született. Az első felfogás szerint a jövő kiszámítható a múlt és a jelen ismeretei alapján. Minél több adatot gyüjtünk a jelenben, annál pontosabb lesz a jövőre vonatkozó elörejelzésünk. Lényegében statisztikai számításokon alapul a jövőkép kialakítása.

A második esetben a jövő fejlődő, mely egy kaotikus és kontrollálatlan modellt követ, és azt kiszámíthatatlan utakon éri el. Ez a megközelítés feltételezi, hogy a jövő eseményeinek ellenőrzése lehetetlen, így intuitív gondolkodás vezet el a jövő jobb megismeréséhez.

A harmadik modellben feltételezik, hogy a jövő képlékeny. Itt a jövő eseményei nem kiszámíthatóak, de nem is kaotikusak. A jövő eseményei manipulálhatók, és azokra a saját cselekvéseink hatással vannak. Ez a megközelítés megbízik a stratégiák kialakításában, melyek lehetővé teszik a jövő formálását, célok kitűzését és azok megvalósítását.

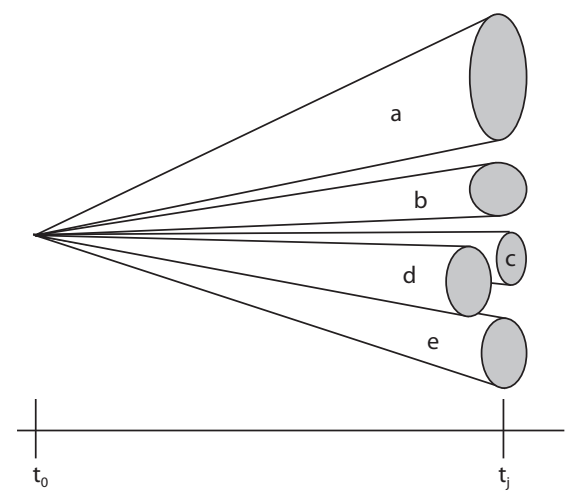

A biztonsági környezetet meghatározó tényezők lehetséges jövőbeni elrendezései

1. ábra A jövő lehetséges alakulása

2 George Friedman: The Next 100 Years: A Forecast for the $21^{\text {st }}$ Century. Kindle version, 26. 01. 2010., 9.

3 Hannah Kosowm - Robert Gaßne: Methods of Future and Scenario Analysis. Deutsches Institut für Entwicklungspolitik (DIE), 2008, 15. https://www.die-gdi.de/uploads/media/Studies_39.2008.pdf (Letöltés időpontja: 2020. 04. 12.) 
Az 1. ábra híven szemlélteti a jövőkutatás nehézségeit, és bemutatja, hogy a jelenböl milyen utakon, milyen jövőképek alakulhatnak ki. Ez a sokfajta út kifejezi, hogy bármilyen szcenáriót is ír le egy adott elemzés, az előrejelzés bizonytalansága az idő előrehaladtával nő. Ezzel együtt nő a lehetséges jövőképek száma is, ezért a hosszú távú tervezés tudományos alapokon nyugvó megközelítést követel meg a területtel foglalkozóktól, így a haderöfejlesztéssel foglalkozó szakemberektől is.

Az MH fejlesztését nem lehet tíz- és négyéves távlatokban kezelni, ahogy azt a jelenleg használt tervezésben alkalmazzák. Tény, hogy a forrásokat a gazdaság tíz évre jelzi előre, de ez nem jelenti azt, hogy a stratégiai irányok kitüzését mellőzni kell. Ezek elhagyása ismételten csak a források nem megfelelö felhasználásához, elherdálásához vezet. Meg kell találni tehát azokat a módszereket, amelyek segítik a jövő haderejének kialakítását.

\section{AZ ÁLTALÁNOS MORFOLÓGIAI ELEMZÉS FOGALMA}

Az általános morfológiai elemzés $\left(\mathrm{GMA}^{4}\right)$ atyja Fritz Zwicky ${ }^{5}$ volt, aki csillagászati kutatásai közben vizsgálta a kapcsolatot a többdimenziós, nem számszerüsíthető problémakomplexumokkal. Ekkor fejlesztette ki a módszere alapjait. Zwicky a módszert több esetben alkalmazta az asztrofizikai objektumok keresése, a rakétameghajtás, továbbá az ürutazással kapcsolatos jogi problémák területén. Azóta a kidolgozott rendszer elterjedt, és a számítógépes támogatásokkal egyre szélesebb körben alkalmazzák a politikai elemzések elkészítésekor és a jövőkutatásokban. Zwicky kiemelte, hogy: „,... a végső és igaz világképben minden kapcsolatban lesz mindennel, semmit nem lehet figyelmen kívül hagyni és eleve nem fontosnak bélyegezni." ${ }^{\circ}$

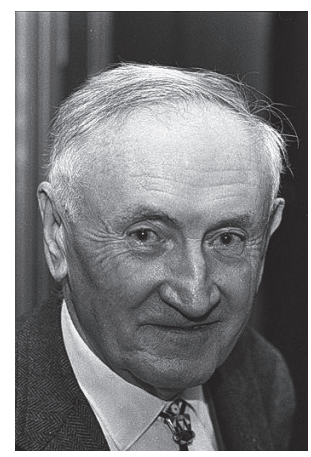

2. ábra Fritz Zwicky ${ }^{7}$

A fenti megállapítás is hangsúlyozza a nem számszerüen elemezhető rendszerek komplexitását, valamint a tényt, hogy egy rendszer minden eleme fontos és figyelembe kell venni.

4 General Morphological Analysis.

5 Fritz Zwicky - Developed General Morphological Analysis. http://www.swemorph.com/zwicky.html (Letöltés időpontja: 2020. 02. 02.)

6 Fritz Zwicky: Discovery, Invention, Research - Through the Morphological Approach. Macmillian Company, Toronto, 1969.

7 http://mathshistory.st-andrews.ac.uk/PictDisplay/Zwicky.html (Letöltés időpontja: 2020. 04. 12.) 
A jövőkutatás, a jövőre vonatkozó szcenáriók kidolgozása több metodikai problémát felvet. Elsőként azt, hogy az adatok a legtöbb esetben nem számszerüsíthetők, mert azok minden esetben politikai, gazdasági, katonai, szociális, információs és infrastrukturális elemeket tartalmaznak. Ez azt eredményezi, hogy a kvantitatív elemzési módszereket nem, vagy csak az adatok egy bizonyos körében lehet alkalmazni az adatok feldolgozása során. Másodsorban a rendszerekben meglévő bizonytalanságokat nem lehet csökkenteni, azokat nem lehet numerikusan jellemezni és leírni.

Végezetül a levont következtetések egy hagyományos elemzési módszerrel olyan kifejezéseket tartalmazhatnak a jövőkutatások eredményeit illetően, mint a „ritkán” vagy a „körülbelül”. Látható, hogy ezek az elemzési módszerek nagy bizonytalanságot tartalmazhatnak, de felmerül a kérdés: Milyen módon lehetséges olyan metodika kialakítása, mely a nem kvantitatív módszereknek is megfelelő tudományos alapokat biztosít?

Zwicky munkássága alapján már javasolta egy általánosított formáját az általa megalkotott módszernek: „Nagy figyelem irányul arra a tényre, hogy a morfológia kifejezést a tudomány sok területén alkalmazzák, hogy jelöljék a strukturális összefüggéseket a kutatásokban - mint például anatómia, geológia, botanika és biológia. ...Azt javasoltam, hogy általánositsuk és foglaljuk rendszerbe a morfológiai kutatást, és ne csak a geometriai, geológiai, biológiai struktúrák tanulmányozására alkalmazzuk, de az absztraktabb strukturális összefüggések tanulmányozására is alkalmazzuk a jelenségek, koncepciók és ötletek kialakitása során, bármilyen is legyen a karakterük."8

A GMA lényegében egy módszer, egy metodika a lehetséges konfigurációk és kapcsolataik elemzésére egy adott, komplex problématerület esetén. Alkalmazása azzal kezdődik, hogy a probléma elemeit, tényezőit, kategóriáit megállapítjuk. Erre bármilyen más módszer is alkalmas lehet, mint például az általam választott közös gondolkodás (brainstroming) rendezett keretek között. A kapott adatokat ezután egy morfológiai mezőben kell elhelyezni.

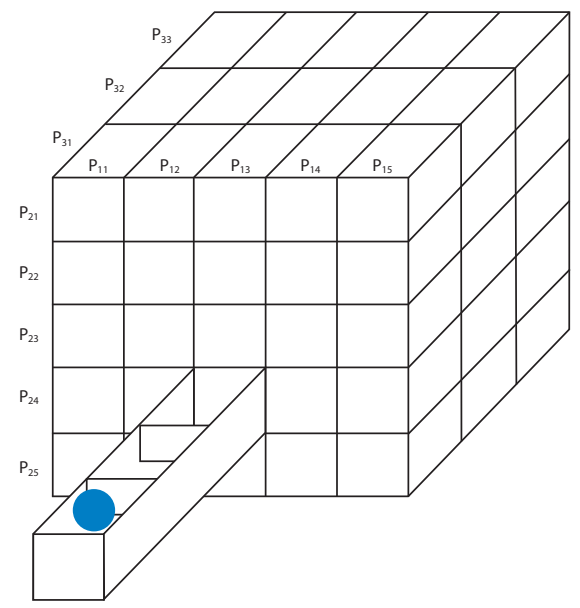

3. ábra A morfológiai mezö, más néven a Zwicky-mezö modellje ${ }^{9}$

\footnotetext{
8 Tom Ritchey: Morphological Analysis - A general method for non-quantified modelling. Adapted from a paper presented at the 16th Euro Conference on Operational Analysis, Brussels, July 1998, 3. http://www.swemorph. com/pdf/gma.pdf (Letöltés időpontja: 2020. 02. 02.)

9 Zwicky: i. m. 116.
} 
A morfológiai mező egy „n dimenziójú” mátrix, ahol annak minden eleme kapcsolódik a többi elemhez. Ebben az ún. „Zwicky-mezőben” (3. ábra) minden kis fiók egy elemet tartalmaz. Ebből már látható a rendszerben vizsgálatnak alávethető kombinációk száma is. A fenti példa esetében ez $5 \times 5 \times 3=75$ kombinációs lehetőség. Itt kijelenthető már az is, hogy a példában feltételezett jövökép 75 fajta módon alakulhat ki.

A morfológiai mező térképszerüen kiterített változatát a 4. ábra mutatja példaként, melyben hat fő kategóriát találunk. Mindegyik kategória tartalmaz elemeket. Ez a fajta megközelítés lehetővé teszi, hogy többdimenziós tereket kiterítve szemléljünk és áttekinthetővé tegyük. A példában bemutatott morfológiai mező $5 \times 4 \times 5 \times 2 \times 6 \times 4$ elemmel 4800 különböző lehetséges kombinációt tesz lehetővé.

\begin{tabular}{|c|c|c|c|c|c|}
\hline Kategória $A$ & Kategória B & Kategória C & Kategória D & Kategória $\mathrm{E}$ & Kategória $\mathrm{F}$ \\
\hline Tényező A1 & Tényező B1 & Tényező C1 & Tényező D1 & Tényező E1 & Tényező F1 \\
\hline Tényező A2 & Tényező B2 & Tényező C2 & Tényező D2 & Tényező E2 & Tényező F2 \\
\hline Tényező A3 & Tényező B3 & Tényező C3 & & Tényező E3 & Tényező F3 \\
\hline Tényező A4 & Tényező B4 & Tényező C4 & & Tényező E4 & Tényező F4 \\
\hline Tényező A5 & & Tényező C5 & & Tényező E5 & \\
\hline & & & & Tényező E6 & \\
\hline
\end{tabular}

4. ábra Morfológiai mezö (Szerkesztette a szerzö)

A komplex probléma elemeinek ilyen irányú, a többdimenziós struktúrába való rendezésével már megoldottuk a nem kvantitatív elemzés egyik problémáját, az adatok szisztematikus rendezését. A NATO-ban alkalmazott kategorizálást megismételve lehetnek politikai, katonai, gazdasági, szociális, információs és infrastrukturális kategóriák. Ez a fajta megközelítés természetesen korántsem kötött, így lehet több kategória is változó számú tényezővel mindegyik alatt. Például lehetnek a biztonságra ható stratégiai trendek, éghajlatváltozás stb. Ha példaként csak egy egyszerü $10 \times 10$-es mátrixot tételezünk fel, 10 elemmel oszloponként, a lehetséges kombinációk száma már $10^{10}$-en eredményt ad. Ekkora mennyiségü adat feldolgozása azonban szinte lehetetlen, így a rendszerben bizonyos megkötéseket is szükséges alkalmazni.

\section{A KERESZTKONZISZTENCIA ALKALMAZÁSA A MODELLEN}

A fent bemutatott többdimenziós modellben természetesen és magától értendően vannak jelen olyan kapcsolatok is, melyek nem létezhetnek egymás párjaként, így a modellből ki kell szürni ezeket. Az elemzés a keresztkonzisztencia-vizsgálattal valósítja meg a nem öszszetartozó elempárok kiszürését, első körben kezdve azokkal az elemekkel, melyek már eleve kizárják egymást.

A keresztkonzisztencia-elemzés azon a feltételezésen alapul, hogy a morfológiai mezőben léteznek olyan természetes párok, melyek alapvetően nem összeegyeztethetők egymással. Példaként említhető a házak minőségi követelménye, mely nem egyeztethetö össze a házak földrajzi elhelyezkedésével, hiszen alapvetően a minőségi elöírások minden házra egyöntetüen vonatkoznak.

A megfelelő eredmények kialakítása érdekében a keresztkonzisztencia-mátrixba rendezzük a morfológiai mező adatait, így azok összevethetők egymással. Az 5. ábra egy ilyen mátrixot szemléltet, ahol az össze nem illő párokat példaként egy-egy „X”-szel jelöltem. 


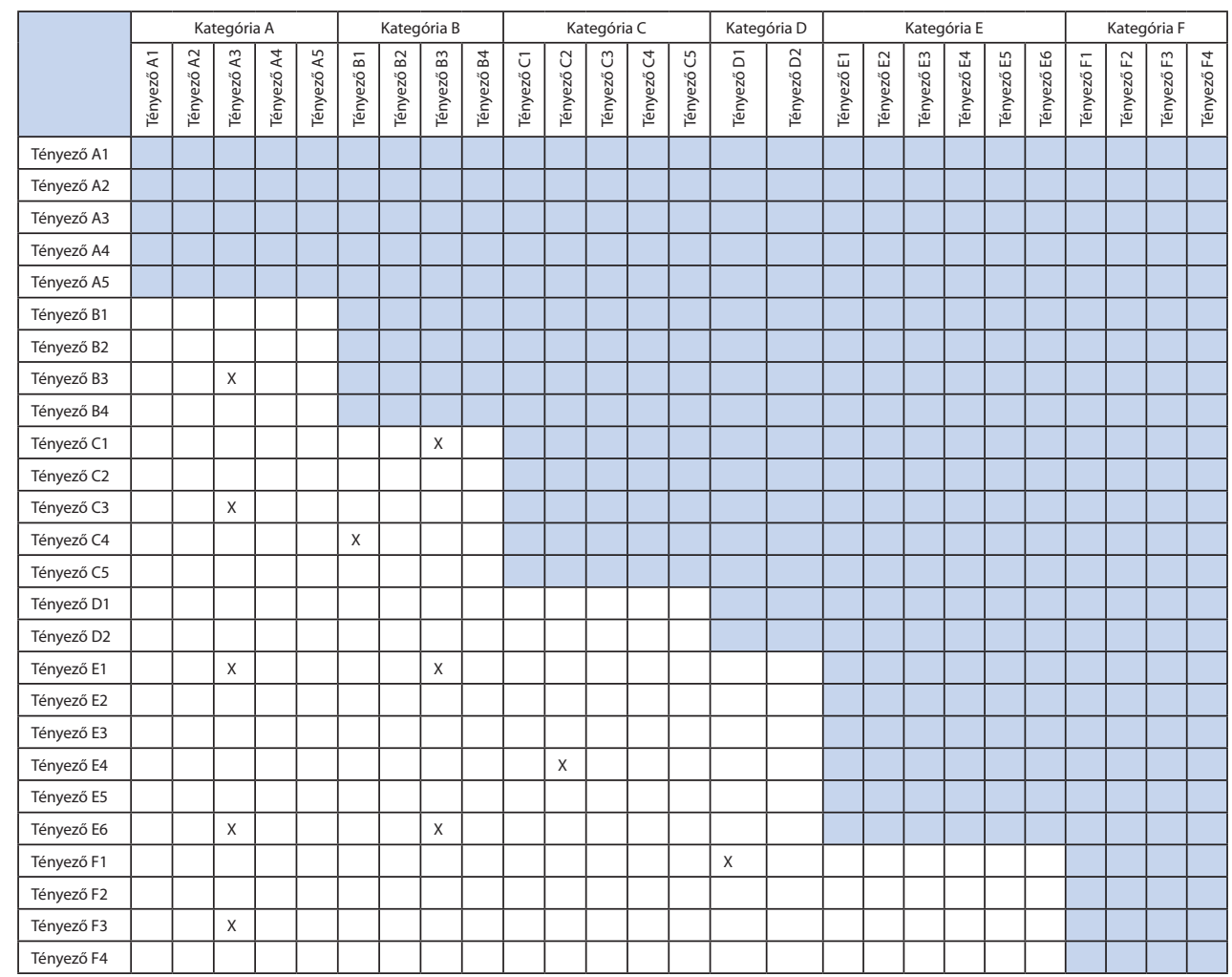

\section{5. ábra Keresztkonzisztencia-mátrix (Szerkesztette a szerzö)}

Ebben az elrendezésben az összes elemet összevetjük a másikkal, valamint elemezzük, hogy az adott kapcsolat létezhet-e a jövőbeni környezetben.

Az adatok összevetésére három alapvető megítélési forma létezik. A logikai kapcsolatok esetén egyszerü logikai érvek alapján döntjük el az adott kapcsolat eredményét. Az empirikus kapcsolat elemzése során elemezzük az adott kapcsolati pár valószínüségét, bekövetkezésének lehetőségét. Normatív kapcsolati elemzéssel az elemek viszonyát etikai vagy például politikai alapokon ítéljük meg. Természetesen az ilyen normatív eljárásokat szükséges elkerülni az elemzések során, mert nem alakítanak ki reális képet a rendszerről, ellenben erősítik az elemzés szubjektivitását.

A keresztkonzisztencia-elemzéssel a morfológiai mezőben kapott kombinációk számát kezelhető szinten tudjuk tartani, ezres nagyságrendről a számokat százas nagyságrend alá lehet csökkenteni. Fontos azonban hangsúlyozni, hogy minden pár kivételét később újra elemezni szükséges, annak érdekében, hogy elkerüljük olyan szcenáriók kialakulását, melyek nem reálisak, továbbá szem előtt kell tartanai, hogy egy-egy pár kivételével a szcenáriót meghatározó adatsor realitása is eltünhet.

Az adatok várható nagy száma miatt elmondható, hogy egy elem felvétele a morfológiai mezőbe exponenciálisan növeli meg a kombinációk számát, így szükséges a szoftveres támogatás kifejlesztése a megoldások kiszámításához. Ezzel modellünk virtuális laboratóriummá válhat, melyben könnyebben elemezhetjük a különböző lehetséges variációkat új változók vagy súlyozás bevezetésével. 


\section{AZ EREDMÉNYEK ELLENŐRZÉSÉNEK LEHETSÉGES MÓDSZERE}

Minden, a tervezés során kapott eredmény csak akkor lehet érvényes és adhat alapot bármilyen tényleges haderőfejlesztési terv végrehajtásához, amennyiben a kapott adatok, szcenáriók helyességét ellenőrizni lehet. Minden tudományágban alapkövetelmény, hogy az elvégzett kísérletek eredményeit más módszerekkel ellenőrizni kell. A jövőelemzés esetében ez az egyik legnehezebb, mert a különböző elméletek más-más megközelítéssel az eredményeket is más módon képezik. Ennek következménye lehet az, hogy eltérő végeredmény jelenik meg az elemzésekben és az ellenörzések során.

Véleményem szerint a jövőképek kialakítását az általam leírt módszerrel lehet a legteljesebb módon végrehajtani, mert a komplex környezet minden elemét figyelembe veszi, azonban mint minden kutatás esetében, a kapott eredményeket valamilyen módszer segítségével itt is szükséges igazolni és alátámasztani.

A fenti módszerben megkapott adatok bekövetkezése valószínüségének elemzésével lehetséges a jövőképek, ezáltal a kialakított haderőképek felülvizsgálata. E módszer alkalmas az adatok folyamatos követésére és végeredményben a tervezés irányának a megváltoztatására is, ha az szükséges.

Az értékelés elkészítése érdekében mindegyik tényezőt egy 1-től 10-ig terjedő skálán szükséges értékelni, melyben a nagyobb pontszám jelenti a bekövetkezés nagyobb valószínüségét. Az ellenőrzési folyamatba lehet a tervezésben részt vevő szakembereket is bevonni, de az igazán szerencsés az, ha az adatokat nem ismerő, de a témában jártas szakembergárdát vehet részt az adatok ellenőrzésében. Természetesen ez nem minden esetben lehetséges, ezért az összes - már az előző vizsgálat elkészítésébe is bevont - szakértő véleményét szükségesnek tartom figyelembe venni az ellenőrzések elkészítésénél. Ezt követően átlagolni kell az adatokat, majd a közepes eltéréseket kell kiszámítani mindegyik adat esetében.

Példaként: egy morfológiai mező alapján kialakított kétfajta szcenárió elemzését elvégezve a 6 . ábra bemutatja a hatás/bekövetkezés valószínüsége vizsgálatot. A táblázatban

\begin{tabular}{|c|c|c|c|c|c|c|c|c|c|c|c|c|c|}
\hline & \multicolumn{2}{|c|}{1} & \multicolumn{2}{|c|}{2} & \multicolumn{2}{|c|}{3} & \multicolumn{2}{|c|}{4} & \multicolumn{2}{|c|}{ Átlag } & \multicolumn{2}{|c|}{ Szórás } & \multirow[b]{2}{*}{$\begin{array}{l}\text { Koc- } \\
\text { kázat }\end{array}$} \\
\hline & Hatás & $\begin{array}{c}\begin{array}{c}\text { Való- } \\
\text { színú- } \\
\text { ség }\end{array} \\
\end{array}$ & Hatás & $\begin{array}{c}\text { Való- } \\
\text { színú- } \\
\text { ség }\end{array}$ & Hatás & $\begin{array}{c}\text { Való- } \\
\text { színú- } \\
\text { ség }\end{array}$ & Hatás & $\begin{array}{c}\text { Való- } \\
\text { színú- } \\
\text { ség }\end{array}$ & Hatás & $\begin{array}{l}\text { Való- } \\
\text { színü- } \\
\text { ség }\end{array}$ & Hatás & $\begin{array}{l}\text { Való- } \\
\text { színú- } \\
\text { ség }\end{array}$ & \\
\hline $\begin{array}{l}\text { Automata rendszerek elterjedtek minden } \\
\text { szegmensben, így a védelmi szektorban is }\end{array}$ & 8 & 10 & 7 & 9 & 8 & 10 & 9 & 8 & 8 & 9,25 & 0,50 & 0,75 & 26,5 \\
\hline Új gazdasági nagyhatalom (Kína) & 5 & 5 & 4 & 4 & 6 & 6 & 6 & 7 & 5,25 & 5,5 & 0,75 & 1,00 & 16,25 \\
\hline $\begin{array}{l}\text { Nagyhatalmi, középhatalmi törekvések inten- } \\
\text { zívek (USA, RUS, CHN, TUR) }\end{array}$ & 6 & 6 & 6 & 7 & 4 & 8 & 5 & 9 & 5,25 & 7,5 & 0,75 & 1,00 & 20,25 \\
\hline Környezeti hatások mérsékeltek & 4 & 2 & 3 & 1 & 2 & 3 & 2 & 1 & 2,75 & 1,75 & 0,75 & 0,75 & 6,25 \\
\hline A szövetségi rendszer (EU, NATO) fennmarad & 5 & 8 & 4 & 9 & 4 & 9 & 3 & 9 & 4 & 8,75 & 0,50 & 0,38 & 21,25 \\
\hline Terrortámadások szélsőséges szervezetek által & 4 & 7 & 4 & 8 & 5 & 8 & 5 & 9 & 4,5 & 8 & 0,50 & 0,50 & 20,5 \\
\hline Poliferáció & 2 & 6 & 1 & 7 & 1 & 5 & 2 & 8 & 1,5 & 6,5 & 0,50 & 1,00 & 14,5 \\
\hline $\begin{array}{l}\text { Automata rendszerek elterjedtek minden } \\
\text { szegmensben, így a védelmi szektorban is }\end{array}$ & 8 & 10 & 7 & 7 & 8 & 8 & 9 & 10 & 8 & 8,75 & 0,50 & 1,25 & 25,5 \\
\hline $\begin{array}{l}\text { Verseny az energiahordozóhoz való } \\
\text { hozzáférésért }\end{array}$ & 5 & 4 & 7 & 5 & 6 & 7 & 9 & 3 & 6,75 & 4,75 & 1,25 & 1,25 & 16,25 \\
\hline Oroszország szétesik & 8 & 2 & 7 & 4 & 7 & 3 & 9 & 2 & 7,75 & 2,75 & 0,75 & 0,75 & 13,25 \\
\hline $\begin{array}{l}\text { Hozzáférés a vízhez nem valósul meg (ivóvíz, } \\
\text { mezőgazdaság) }\end{array}$ & 6 & 7 & 8 & 8 & 7 & 8 & 7 & 6 & 7 & 7,25 & 0,50 & 0,75 & 21,5 \\
\hline $\begin{array}{l}\text { Éghajlatváltozás felgyorsul, nagyarányú katasz- } \\
\text { trófák általánosak }\end{array}$ & 9 & 5 & 8 & 4 & 8 & 3 & 9 & 4 & 1,5 & 4 & 0,50 & 0,50 & 16,5 \\
\hline $\begin{array}{l}\text { A szövetségi rendszer (EU, NATO) széthullik, } \\
\text { MO. önálló }\end{array}$ & 7 & 3 & 8 & 2 & 8 & 1 & 8 & 2 & 7,75 & 2 & 0,38 & 0,50 & 11,75 \\
\hline Általános háború Európában & 9 & 2 & 9 & 3 & 9 & 3 & 9 & 5 & 9 & 3,25 & 0,00 & 0,88 & 15,5 \\
\hline
\end{tabular}

6. ábra A lehetséges jövők hatás-, illetve valószinüség-táblázata (Szerkesztette a szerzö) 


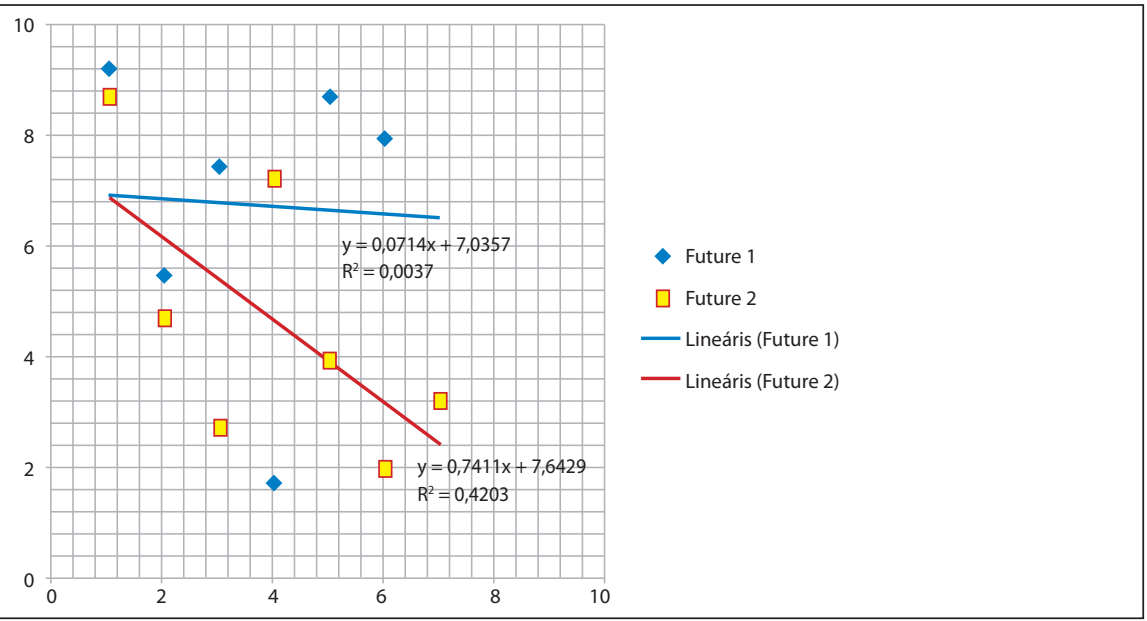

7. ábra A lehetséges jövőképek bekövetkezési valószinüség grafikonja (Szerkesztette a szerzö)

példaként négy különböző „szakértői” adatot jelenítettem meg, ezzel is jelezve, hogy minden szakértő véleményét figyelembe kell venni a vizsgálat során. A táblázatban a szakértők minden tényezőt 1-től 10-ig skálán értékeltek, a bekövetkezés valószínüsége, valamint annak hatása vonatkozásában.

A táblázatban megjelenített adatok felmérése történhet közvetlen módon a szakértők tényleges részvételével egy megbeszélésen, de történhet felmérö kérdőívek szétküldésével is. Jelen feladatot célszerübb elektronikus felmérés elkészítésével végrehajtani, mert ez nem követeli meg különös erőforrások felhasználását.

A táblázatban a hatás/valószínúség adatait átlagoltam, majd minden adatsorhoz kiszámítottam a szórás mértékét. A fenti adatsorban a nagyobb szórás mértéke az adatok közötti eltérés nagyságát határozza meg. Az adatok szórásának mértéke jelzi, hogy a szakértők véleménye az adott tényező vonatkozásában mennyire tér el egymástól. Nagy szórásérték a szakértők erős véleménykülönbségét jelzi, míg a kicsi eltérés a szakértők egyező véleményét fejezi ki egy adott tényező vonatkozásában. A nagy eltérést mutató adatokat további vizsgálatnak szükséges alávetni. A kis szórásértékek esetében további elemzés lehetséges, de csak ellenőrzés céljából, az esetleges hibák kiszürése érdekében. Itt kijelenthető, hogy az adott tényező nagy valószínüséggel azt a trendet fogja követni, melyet a szakértők is meghatároztak a kidolgozás során.

A szórás vizsgálatát követően a valószínüségi változók elemzését is szükséges elvégezni. A 7. ábrán grafikus formában jelenítettem meg a szakértők által megadott valószínúségi adatokat. Az egyes adatok átlagolásával kapott értékeket pontdiagramban ábrázolva, majd azokra egy lineáris trendvonal felvételével ábrázolhatjuk az adatok trendvonalhoz való viszonyát. A trendvonal irányát jelen példában nem vettem figyelembe.

A bekövetkezési valószínüség vizsgálata jó közelítést ad a lehetséges jövőképek vizsgálatához, de szükségesnek tartom az adatok kockázatelemzésének az elvégzését is. A 8. ábrán látható kockázatok kiszámítását a $\mathrm{K}=\mathrm{P}+2 \times \mathrm{I}^{10}$ képlettel végeztem el, ahol:

${ }^{10}$ Dr. Daróczi Miklós: Projektmenedzsment. 16. fejezet: A kockázati tényezők hatásának elemzése, a kockázatkezelés eszközei. Szent István Egyetem. http://www.tankonyvtar.hu/hu/tartalom/tamop412A/2010-0019_Projektmenedzsment/ch16.html (Letöltés időpontja: 2020. 02. 02.) 
- $\mathrm{K}$ - a kockázati együttható; ${ }^{11}$

- $\mathrm{P}$ - a valószínüség mértéke;

- I - az esemény hatása a biztonságra.

A fenti képletben a különböző tényezők biztonságra való hatását korrekciós tényezőként súlyoztam 2-vel. ${ }^{12}$ Természetesen a kidolgozó csoport a helyzet ismeretében a valószínúségi együtthatókat is súlyozhatja, illetőleg minden egyes tényező súlyát külön is meghatározhatja, ezzel adva jobb közelítéseket a számításokhoz.

A kockázati együttható mértéke a fenti képlet alkalmazásával - az 1-től 10-ig történő értékelési szempont alapján - nullától 30-ig terjedhet, melyet grafikonon ábrázolok. A kockázat mértékét a grafikonon leolvasva kidolgozható a magas és az alacsony kockázatú tényezők rendszere is.

Példánkban a magas kockázatú tényezőkre $\mathrm{K}=24$, a közepes kockázatú tényezőkre $K=20$, az alacsony kockázatú tényezőkre pedig $K=10$ értékét vezethetjük be. $K=10$ érték alatt elhanyagolható kockázati mértékről beszélhetünk. A grafikon jobb felső része a magas, a bal alsó része pedig az alacsony kockázatokat jelenti.

A kiszámított kockázati együtthatókat grafikonon ábrázolva a 8. ábra szemlélteti.

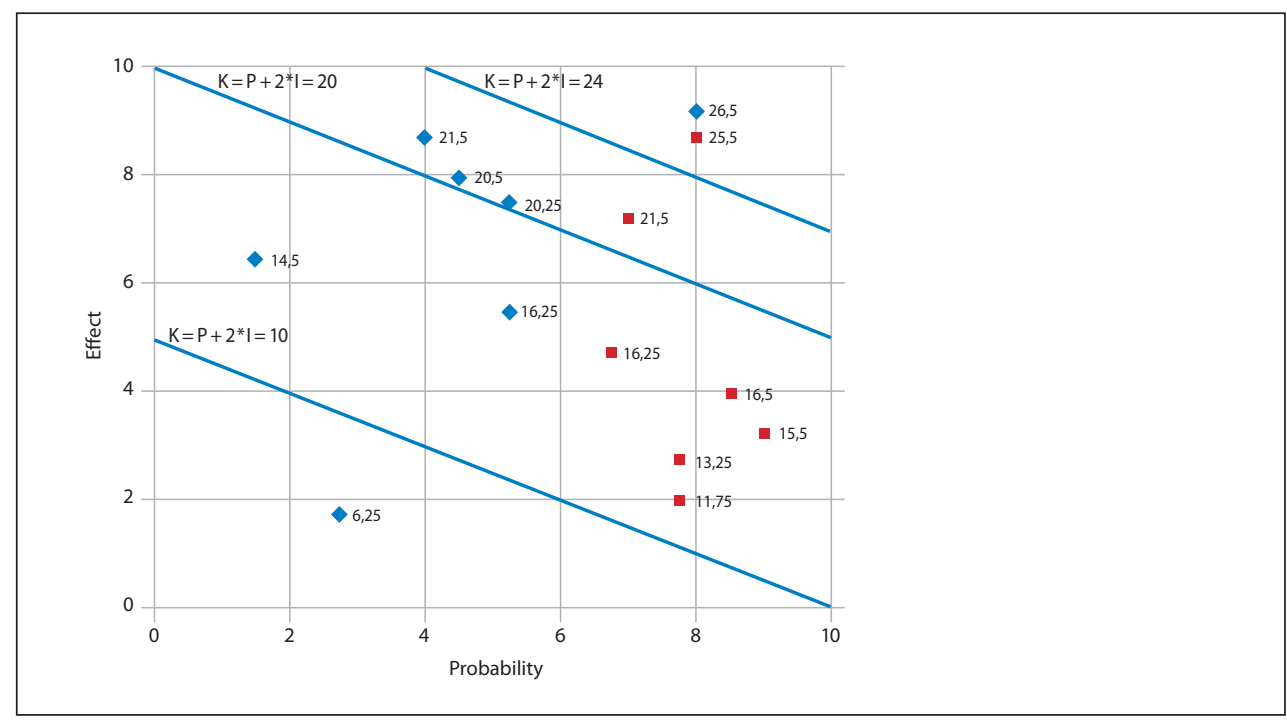

8. ábra A lehetséges jövőképek kockázati grafikonja (Szerkesztette a szerzö)

${ }^{11}$ Fekete István $\mathrm{PhD}$-dolgozatában a $\mathrm{K}=\mathrm{k} \times \mathrm{P} \times \mathrm{I}$ képletet alkalmazza a kockázati együttható kiszámításához, majd a dolgozatban adott példához ezt egyszerüsítve a $\mathrm{K}=\mathrm{P} \times \mathrm{I}$ képletet alkalmazza. Kiemeli: „képletben a korrekciós tényezőnek akkor lehet szerepe, ha egy kockázati tényező értékelését több hatástényezőre kell elvégezni. Ilyenkor az értékelést minden egyes hatástényezőre külön-külön elvégezzük és ezen értékelés során a k korrekciós tényező alkalmazásával lehet súlyozni a különböző hatástényezőket (ha szükséges).” Fekete István: A kockázatelemzés szerepe a beruházások pénzáramlásának meghatározásában. Doktori (PhD-) értekezés, Budapesti Műszaki és Gazdaságtudományi Egyetem, 2000. http://unipub.lib.uni-corvinus.hu/638/1/fekete_i_phd. pdf (Letöltés időpontja: 2020. 02. 02.)

12 A tényezők súlyozását a művelettervezés során a cselekvési változatok kidolgozása esetén alkalmazott módszerrel javasolt megoldani. 
A meghatározott jövőképek ellenőrzését természetesen több módszerrel el lehet végezni, de azokat már a tervezés megkezdése előtt rögzíteni szükséges, így a tervezőcsoportnak nem a feladat-végrehajtás során kell meghatároznia a módszereket és kidolgozni az eljárásokat az ellenőrzések végrehajtására. Célszerü külön csoportot csak erre a feladatra kialakítani, amelynek tagjai már a teljes folyamat ismeretében tudják meghatározni a legmegfelelőbb eljárást az adatok megbízhatóságának legpontosabb meghatározására.

\section{ÖSSZEGZÉS}

A NATO-nak, de tagállamainak még inkább át kell tekinteni a haderöfejlesztésre kapott források elköltésének módját, felügyeletét, mert a ma meghozott döntéseknek a jövőben lesz hatásuk. A mai döntések határozzák meg a jövő haderejének típusát, felszereltségét, feladatrendszerét és képességeit. Fontos kiemelni, hogy az érdekek és szándékok gyorsan változhatnak, de a képességek fejlesztése a hadseregekben csak lassan módosul, így a haderők fejlesztését biztos alapokra kell helyezni. További alapkövetelményként kell lefektetni, hogy döntéseinkkel mindig egy lépéssel a lehetséges szemben álló felek előtt járjunk. Ennek érdekében a jelenlegi képességeink felmérésével és a stratégiai trendek folyamatos értékelésével, a jövő lehetséges legpontosabb megtervezésével kell meghatároznunk a haderö jövöbeni feladatait és felépítését.

Véleményem szerint a leírt folyamat alkalmas az MH haderőfejlesztési feladatainak megalapozására, a stratégiai célok részletes megfogalmazására.

\section{FELHASZNÁLT IRODALOM}

Dr. Daróczi Miklós: Projektmenedzsment. 16. fejezet: A kockázati tényezök hatásának elemzése, a kockázatkezelés eszközei. Szent István Egyetem. http://www.tankonyvtar.hu/hu/tartalom/tamop412A/2010-0019_Projektmenedzsment/ch16.html

Fekete István: A kockázatelemzés szerepe a beruházások pénzáramlásának meghatározásában. Doktori (PhD-) értekezés, Budapesti Müszaki és Gazdaságtudományi Egyetem, 2000. http://unipub. lib.uni-corvinus.hu/638/1/fekete_i_phd.pdf

Friedman, George: The Next 100 Years: A Forecast for the 21 ${ }^{\text {st }}$ Century. Kindle version, 26. 01. 2010.

Fritz Zwicky - Developed General Morphological Analysis. http://www.swemorph.com/zwicky.html

Kosow, Hannah - Gaßne, Robert: Methods of Future and Scenario Analysis. Deutsches Institut für Entwicklungspolitik (DIE), 2008. https:/www.die-gdi.de/uploads/media/Studies_39.2008.pdf

Nováky Erzsébetnek a Budapesti Corvinus Egyetem Jövőkutatás Tanszéke és a Magyar Szakképzési Társaság Kutatói Tagozata 2004. június 28-i ülésén tartott előadásának írásos változata. Szakképzési Szemle, 2005/3., 290-316.

Ritchey, Tom: Morphological Analysis - A general method for non-quantified modelling. Adapted from a paper presented at the $16^{\text {th }}$ Euro Conference on Operational Analysis, Brussels, July 1998. http://www.swemorph.com/pdf/gma.pdf

Zwicky, Fritz: Discovery, Invention, Research - Through the Morphological Approach. Macmillian Company, Toronto, 1969. http://mathshistory.st-andrews.ac.uk/PictDisplay/Zwicky.html 